\title{
Tradycja wojny Starotestamentowej w literaturze rosyjskiej a Armia konna Izaaka Babla
}

\author{
Wojciech Gorczyca (Polsko)
}

\begin{abstract}
Abstrakt
Autor śledzi topos wojny Starotestamentowej w literaturze staroruskiej (np. Żywot Aleksandra Newskiego) i rosyjskiej (Wojna i pokój Lwa Tołstoja). Za reprezentatywną pod tym względem uważa wojnę obronną w Biblii, jaką była bitwa z Amalekitami. Teksty reprezentujące ów topos koreluje z odpowiednimi kontekstami etycznymi, politycznymi i religijnymi, w tym z dwoma mitami ideologicznymi: Moskwą jako Trzecim Rzymem oraz Nową Jerozolimą. Według autora, wojnę polsko-bolszewicką (1919-1920) Babel odczytuje właśnie jako wojnę obronną, wypaczając fakty historyczne. Jednocześnie Babel wypacza ustalenia Starego Testamentu w kwestii relacji: zabijanie - mordowanie. Bóg Starotestamentowy nie jest przeciw zabijaniu, ale raczej przeciw mordowaniu. Babel nie ma nic przeciwko mordowaniu Polaków i Żydów przez Armię Konną.
\end{abstract}

\section{Słowa kluczowe}

literatura staroruska i rosyjska; wojna obronna w Biblii; bitwa z Amalekitami; Wojna i pokój Lwa Tołstoja; wojna polsko-bolszewicka 1919-1920; wypaczanie faktów historycznych i ustaleń Starego Testamentu przez Babla

\section{Abstract \\ The Tradition of the Old Testament War in the Russian Literature and Isaac Babel's Red Cavalry (Konarmiya)}

The author follows the topos of the Old Testament War in the Old Russian Literature (e.g. Life of Alexander Nevsky) and the Russian literature (Lev Tolstoy's War and Peace). According to the author, the most representative war was a defence war in the Bible, that is the war with Amalekites. The autor correlates the texts representing this topos with the corresponding etical, political and religious contexts, including two ideological myths: Moscow as the Third Rome and New Jerusalem. In author's view, the Polish-Bolshevik War (1919-1920) was seen by Babel as a defence war, which is a distortion of historical facts. At the same time, Babel distorts the foundations of the Old Testament concerning the relation: killing - murdering. The Old Testament's God is not opposed to killing, but rather - murdering. Babel has nothing against murdering Poles and Jews by the Cavarly.

\section{Key words}

Old Russian and Russian Literature; defence war in the Bible; the war with Amalekites; Lev Tolstoy's War and Peace; the Polish-Bolshevik War 1919-1920; distortion of historical facts and foundations of the Old Testament by Babel 
Piszac o Armii konnej (Конармия, 1926) Izaaka Babla, I. Makarowa stwierdza: „[...] cata symbolike swego tekstu Babel czerpie ze Starego, a nie Nowego Testamentu, gdzie, z wyjatkiem Proroctw, wolno zabijać, zadawać śmierć, stosować przemoc". ${ }^{1}$ Ocena Makarowej, jakkolwiek słuszna, jest moim zdaniem jednostronna i należałoby ją opatrzyć kilkoma komentarzami. Biblia tak naprawdę mówi: „Nie powinieneś mordować. Wojna nigdy nie jest dobra rzecza, ale czasami jest czymś potrzebnym. W świecie wypetnionym grzesznymi ludźmi wojna jest nieunikniona." Poza tym spotykamy u Babla próbę wykorzystania motywu pastucha-pasterza (postać Saszki Chrystusa), który nawiązuje do Jezusa Chrystusa - Dobrego Pasterza.

W Starym Testamencie czytamy o błogosławionych przez Boga wojnach Izraela z Kananejczykami, odpieraniu niesprawiedliwej agresji za pomocą siły zbrojnej, też zbrojnym powstaniu przeciw bałwochwalczej tyranii (Ksiega Jozuego 10; Ksiega Rodzaju 14; 1 Ksiega Samuela 23). Typową wojną obronną w Biblii, którą w literaturze rosyjskiej odczytać można jako topos, była bitwa z Amalekitami. Bóg za pośrednictwem jednego ze swych proroków nawet skarcił Izraelitów za niedokładne wykonanie wybicia Amelekitów (1 Księga Samuela 15).

Topos wojny obronnej i sprawiedliwego władcy Mojżesza (również Dawida oraz Salomona) oparty na biblijnym starciu Izreaelitów z Amalekitami spotykamy w Żywocie Aleksandra Newskiego, Stowie o życiu i śmierci wielkiego księcia Dymitra Iwanowicza cara ruskiego, Listach Iwana Groźnego do Stefana Batorego oraz w Wojnie i pokoju Lwa Tołstoja. Topos ów w literaturze rosyjskiej opiera się na podstawie spekulatywno-konstrukcyjnej - odwracaniu prawdy historycznej i odpowiedniej prefiguracji, która eksponuje motyw ofiarnictwa ze strony rosyjskiej i zaborczość wroga (Kawalerów Mieczowych, Tatarów Mamaja, króla Stefana Batorego, Napoleona).

Jeśliby rozpatrywać zawartą w tytule artykułu implikaturę dotyczącą wojny Starotestamentowej i jej obecności w literaturze rosyjskiej z punktu widzenia badań kulturowych, w tym szczególnie podejścia etyczno-politycznego, ${ }^{3}$ to należałoby odnieść się do dwóch podstawowych kwestii:

- wojny w obronie pogaństwa (Aleksander Newski) i chrześcijaństwa (Iwan Groźny) oraz przeciw pogaństwu (Dymitr Doński i Iwan Groźny),

- wojny z wrogiem, który uprzednio był sojusznikiem i z którym zawarto odpowiednie traktaty (np. Mamaj i Dymitr Doński oraz Aleksander I i Napoleon).

Kwestie te, według mnie, mają ścisły związek z pojęciem przemocy symbolicznej, z językiem jako częścią gry wymiany kulturowej, która zakłada konflikt interesów i walkę o władzę symboliczną, czyli o moc oddziaływania na świat poprzez działanie na wyobra-

1 MAKAROVA, I. A.: Socialističeskij realizm. In: Russkaja literatura XX veka. Red. S. I. Tišina. Sankt-Peterburg 2002, s. 221-237.

2 Księa Rodzaju 20: 30; List do Rzymian 3: 10-18. In: Pismo Święte w przekładzie Nowego Świata. Nowy Jork: Towarzystwo Biblijne i Traktatowe, 1997.

3 MARKOWSKI, Michał Paweł: Badania kulturowe. In: Teorie literackie XX wieku. Red. A. Burzyńska i tenże. Kraków: Universitas, 2007, s. 519 -548; BURZYŃSKA, Anna: Kulturowy zwrot teorii. In: Kulturowa teoria literatury. Gtówne pojęcia i problemy. Red. M. P. Markowski i R. Nycz. Kraków: Universitas, 2006, s. $86-87$. 
żenia o nim. ${ }^{4}$ Tak rozumiane podejście do problemu wojny w Armii konnej jest obce dotychczasowym badaczom twórczości Babla. ${ }^{5}$

Stary Testament z Bogiem karzącym i nawołującym do wojny w obronie swego kraju zaznaczył swą obecność w kanonie tekstów literatury staroruskiej i rosyjskiej, których nie można oddzielić od uwikłań etycznych, politycznych i religijnych, związanych z dwoma mitami ideologicznymi, które określa się jako Moskwa III Rzym i Nowa Jerozolima. ${ }^{6}$ Pierwszy, jak wiadomo, ma właśnie odniesienia polityczne, drugi, religijne. Nowa Jerozolima obok Moskwy III Rzymu stały się na Rusi centrum prawosławnego, a tym samym całego chrześcijańskiego świata. Owo centrum identyfikować można w Żywocie Aleksandra Newskiego oraz Stowie o życiu i śmierci wielkiego księcia Dymitra Iwanowicza cara ruskiego, co ma związek, jak piszą zgodnie Wiktor Jakubowski i James Billington z przeredagowywaniem żywotów świętych za czasów Iwana Groźnego w celu ukazania szczególnego powołania Rusi, w tym oczyszczenia genealogii, hagiografii, historii wojennych z niepotrzebnych opowieści. ${ }^{7}$

Szczególnie powołanym (z chańskiego, tj. pogańskiego nadania) został wielki książę włodzimierski, Aleksander Newski wyświęcony przez Iwana Groźnego w 1547 roku, a więc w roku jego wstąpienia na tron. Współcześnie ocenia się, że Newski, który w $\dot{Z} y-$ wocie przed bitwą z oddziałami Kawalerów Mieczowych na zamarzniętym jeziorze Pejpus wznosi ręce do nieba i prosi Boga o pomoc, wystąpił przeciwko nawracaniu pogan na wiarę chrześcijańską: „Суди ми, боже, и разсуди прю мою от языка препдобна и помози ми, господи, яко же древле Моисею на Амалика". ${ }^{8} \mathrm{~W}$ żadnej z bulli papieskich z lat 1240-1243 nie znajdujemy informacji o działaniach wojennych przeciw Rusinom. Bulle odnoszą się jedynie do walki przeciw niechrześcijanom oraz do misji wśród pogan. ${ }^{9}$ (Fonnesberg-Schmidt 2009, s. 219). Wyprawy nad rzekę Newę i Votię były krucjatami mającymi na celu rozszerzenie zasięgu Kościoła katolickiego. Stąd też twierdzi się, iż Newski w bitwie na jeziorze Pejpus, gdzie doszło 5 kwietnia 1242 roku do spotkania armii chrześcijan z siłami ruskimi, mordował chrześcijan.

4 MARKOWSKI, Michał Pawel: Badania kulturowe. Op. cit., s. 526.

5 DRAWICZ, Andrzej: Lata dwudzieste. Proza. In: Historia literatury rosyjskiej XX wieku. Red. tenże. Wyd 2. Warszawa: PWN, 2002, s. 238; SUCHICH, Igor Nikolajevič: Epos. „Konarmija” I. Babelja. In: Russkaja literatura XX veka. Red. S. I. Tišina. Sankt-Peterburg: 2002, s. 394-417; DUDA, Katarzyna: Literatura rosyjska XX wieku. In: Rosjoznawstwo. Red. L. Suchanek. Kraków: Wydawnictwo Uniwersytetu Jagiellońskiego, 2004, s. 279.

6 BURZYŃSKA, Anna: Kulturowy zwrot teorii. In: Kulturowa teoria literatury. Op. cit., s. 86; GORCZYCA, Wojciech: Iwan IV Grożny. Portret kulturowy wtadcy. Bielsko-Biała: Wydawnictwo Naukowe Akademii Techniczno-Humanistycznej, 2012, s. 24-26, 55.

7 JAKUBOWSKI, Wiktor: Piśmiennictwo zjednoczonego państwa moskiewskiego (1500-1630). In: Historia literatury rosyjskiej. Red. M. Jakóbiec. Warszawa: PWN, 1976, s. 120-126; BILLINGTON, James: Ideologia Moskiewska. In: Chrześcijaństwo Rusi Kijowskiej. Biatorusi, Ukrainy i Rosji (X-XVII wiek). Red. J. Kłoczowski. Kraków: PAU, 1997, s. 180-190.

8 Żywot Aleksandra Newskiego. In: JAKUBOWSKI, Wiktor - ŁUŻNY, Ryszard. Literatura staroruska: wiek XI-XVII. Antologia. Warszawa: PWN, 1971, s. 95.

9 FONNESBERG-SCHMIDT, Iben: Papieże i krucjaty battyckie 1147-1254. Przeł. B. Solecki. Warszawa: Bellona, 2009, s. 220. 
Newski, jak wiadomo, odrzucił możliwość wspólnego udziału - katolików i prawosławnych - w nawracaniu Tatarów na wiarę chrześcijańska pod egidą papieża Innocentego IV. Miało to niebagatelny wpływ na fakt, iż w 1252 r. został on wyniesiony przez chana Złotej Ordy, Batu chana, do godności wielkiego księcia. Wiernopoddaństwo wobec Mongołów, mordowanie sprzeciwiających się najeźdźcy mieszkańców Rusi, wcielanie ich do armii mongolskiej, to przykłady działań, które przyczyniły się do założenia na północno-wschodnich terenach Rusi cywilizacji, którą po pewnym czasie nazwano azjatycką. Stanął więc Aleksander Newski u źródeł caratu moskiewskiego. ${ }^{10}$

Ocena zwrotu Newskiego do Boga Starotestamentowego i jego prośba o pomoc per analogiam do prośby Mojżesza w bitwie Izraelitów z Amalekitami, w świetle współcześnie funkcjonujących tekstów na temat nawracania pogan mieszkających na ziemiach leżących miedzy Nowogrodem i Pskowem oraz poddanie się Batu chanowi, tudzież odrzucenie intencji nawracania Mongołów na wiarę chrześcijańską, może być dzisiaj jedna. U podstaw „oczyszczania hagiografii i historii wojennych z niepotrzebnych opowieści” leżało wprowadzanie uspołecznionej subiektywności, zbiorowej dyspozycji i preferencji, dzięki którym świat staje się dla jednostki zrozumiały i czytelny. ${ }^{11}$ „Czytelność” w tym wypadku została wypreparowana w oparciu o określoną prefigurację mitu ideologicznego, opartą na substytucji (wymianie elementów) - Newski-Mojżesz; Newski-Salomon i odwróceniu prawdy - Kawalerowie Mieczowi jako Amalekici, tj. poganie, napadają na chrześcijan, tj. plemiona pogańskie. Newski jako chrześcijanin broni owych „chrześcijan” i w konsekwencji przyłącza się do poganina, wyznającego szamanizm, tj. do Batu chana. Szczególnie metafora symbol Newski-Mojżesz i zderzenie jej znaczenia z Amalekitami jest istotnym elementem profilującym mit ideologiczny Moskwy jako III Rzymu i Nowej Jerozolimy.

Z podobną wersją „obrony” chrześcijan mamy do czynienia w Stowie o życiu i śmierci Dymitra Iwanowicza. W przekonaniu autora Stowa Dymitr Doński na Kulikowym Polu (1380 r.) bronił wiary chrześcijańskiej (prawosławia) przed poganami, tj. Tatarami, z którymi kilka lat przed bitwą był w całkiem niezłej komitywie. Jak wiadomo, podczas sytuacji kryzysowej w Złotej Ordzie Dymitr Doński przystąpił do stronników Mamaja, a jego relacje z Tatarami stanowiły element sojuszu. Kiedy sytuacja Mamaja zaczęła słabnąć, Dymitr zerwał z nim stosunki. Finałem konfliktu była bitwa na Kulikowym Polu. Feliks Koneczny stwierdza, iż bitwa ta nie miała stanowić ani o dorobku wolności, ani podstaw potęgi Moskwy. Było to tzw. zwycięstwo Pyrrusowe, ponieważ jego konsekwencją była klęska w 1382 roku, tj. pacyfikacja Rusi przez chana Tochtamysza, spalenie Moskwy, z której Dymitr Doński uciekł. ${ }^{12}$

Stowo mocno eksponuje mit ideologiczny wojny sprawiedliwej („za wiarę”). Z Ksiegi Wyjścia zaczerpnięte zostało w Stowie, podobnie jak w Żywocie Aleksandra Newskiego, po-

10 SZYLNIK, Lew: Czarne dziury historii Rosji. Przeł. M. Leczycka. Warszawa: Bellona, 2011, s. 81.

11 MARKOWSKI, Michał Pawel: Badania kulturowe. Op. cit., s. 536.

12 BUŁAWA, Katarzyna: Tropologiczny sens Żywota Aleksandra Newskiego oraz Stowa o życiu $i$ śmierci wielkiego księcia Dymitra Iwanowicza, cara ruskiego. Studia Slavica XIV, 2010, s. 82-83; GREŃ, Sabina: Mongotowie i Rusini. Stowo o życiu i śmierci wielkiego księcia Dymitra Iwanowicza, cara ruskiego. In: Współczesny świat słowiański, II. Red. K. Feruga i A. Ostrowska-Knapik. Praha: Verbum, 2016, s. 29-37. Dostępne: http:// www.ks.ath.bielsko/plwspolczesny-swiat-slowianski. 
równanie zwycięstwa Dymitra Dońskiego do zwycięstwa Izraelitów nad Amalekitami: „И възратися князь Дмитрийс великою победою якоже прежде Моиси Амалика победив”. ${ }^{13}$ Wojna „za wiarę" nie miała tutaj miejsca, była wojną, którą reprezentowały dwie opcje polityczna i ekonomiczna. Tatarzy nie byli wówczas poganami. W latach 1360-1380 Orda w całości przeszła na islam.

Jak pisze Elżbieta Giejsztor-Miłobędzka, „[...] kietkujaca we wczesnym średniowieczu humanizacja kultu, bujnie rozwinięta w późnym średniowieczu [...] umożliwiata przejście od spekulatywnego symbolu do humanizujacej boskość reprezentacji historycznej." ${ }^{14}$ "Humanizująca boskość" reprezentacja historyczna osiagnęła w kulturze Rosji dwa szczyty - w Listach Iwana Groźnego oraz Wojnie i pokoju Lwa Tołstoja.

Jak wyglądała owa „boskość” w momencie wstąpienia Groźnego na tron? „[...] w czasie ceremonii koronacyjnej Iwana metropolita Makary przyrównał cara do króla Dawida. [...] w jednym zdaniu metropolita nazwał 'carami' Boga, króla Dawida i Iwana. Nawiązująca do Starego Testamentu symbolizację postaci Mojżesza, Jozuego i Gedeona szczególnie intensywnie wykorzystywano po 1547 roku." ${ }^{15}$

Iwan Groźny jako „chorąży Jezusa Chrystusa” unaocznia w Listach dwie kulminacje wojny sprawiedliwej - wojny obronnej, w której występuje jako ofiara i wojny za wiarę. Pierwsza to wojna z Polską o Inflanty, druga to walka z chanatem kazańskim, „reklamowana" przez cara jako wyprawa krucjatowa. ${ }^{16}$ Wiadomo, że Groźny wymusił w 1544 roku na Kawalerach Mieczowych traktat ograniczający samodzielność ich państwa i zakazujący związków z Litwą. Na to bezprawie zareagował król Zygmunt August, również dlatego że arcybiskup ryski został uwięziony, a poseł króla zamordowany. Hetman litewski Mikołaj Radziwiłł odzyskał część utraconych przez Zakon terytoriów i został podpisany tzw. pierwszy traktat wileński. Wkrótce drugi układ wileński z 28 listopada 1561 roku oddał Polsce całe Inflanty na północ od Dźwiny. Na tym zakończyła się pierwsza wojna o Inflanty między Rosją i Polską. Groźny w 1579 roku podjął kolejną bezprawną próbę odbicia Inflant, zakończoną kompletnym niepowodzeniem swoich wojsk, zwycięstwem Stefana Batorego oraz podpisaniem rozejmu w Jamie Zapolskim (1582 r.).

W listach do Stefana Batorego Groźny jako wyznawca Starotestamentowego Boga „Sabaotha”, Boga - Pana Zastępów w swej najbardziej patriarchalnej i karzącej postaci, ${ }^{17}$ doprowadza do melanżu znaczeń Starego i Nowego Testamentu. Jako „chorąży Jezusa Chrystusa” cierpi jak On na krzyżu, oddając swą krew za wiarę chrześcijańską. Z drugiej strony, walczy jak Jozue z Amalekitami w imię Starotestamentowego Boga. Emfatyczne ramy listu Groźnego do Stefana Batorego odnoszą się przede wszystkim do kontrastywnego zestawienia upadku Batorego, jako przelewającego krew chrześcijańską ze zwycięstwem-wzlotem

13 Stowo o życiu i śmierci wielkiego księcia Dymitra Iwanowicza, cara ruskiego. Dostępne: http://www.pushinskijdom.ru/Default.aspx?tabid=4985.

14 GIEYSZTOR-MIŁOBĘDZKA, Elżbieta: Symbol we wnętrzu kościelnym. In: Symbol i poznanie. Red. T. Kostyrko. Warszawa: PWN, 1987, s. 48.

15 PAWŁOW, Andriej - PIERRIE, Maureen: Iwan IV Groźny. Car i tyran. Przeł. Sł. Kędzierski. Warszawa: Bellona, 2008, s. 64.

16 GORCZYCA, Wojciech: Iwan IV Groźny. Op. cit., s. 48-55.

17 PAWŁOW, Andriej - PIERRIE, Maureen: Iwan IV Groźny. Op. cit., s. 184. 
Groźnego jako obrońcy chrześcijaństwa: „И зачем нам давать тебе силу против нас? А если тъ силен, приди и пролей неповинную христианскую кровъ и возъми." 18

Automistyfikację cara w Listach określa swoista alegoria oraz swobodna gra prawdy i zmyślenia. ${ }^{19}$ Jest to jednocześnie przykład teologii politycznej, której wersja legła u podstaw wyprawy krucjatowej na Kazań, wszczętej z pobudek gospodarczych i ekonomicznych. Wyprawa przekonuje, że Moskwa z reguły podbijała narody bądź znajdujące się w stanie kompletnego upadku, bądź niestawiające większego oporu. Państwo Kazańskie padło w chwili wewnętrznej słabości. Kazań-Sodome Moskwa odbudowała jako miasto rosyjskie i centrum rosyjskiego prawosławia. Jednocześnie przejęła od „pogan” elementy ich architektury (tj. architektury islamskiej, kazańskiej). Przykładem jest sobór Wasyla Błogosławionego na Placu Czerwonym w Moskwie.

Na identycznie rozumianej wersji teologii politycznej bazuje Lew Tołstoj, którego nota bene Babel uważał za największego pisarza rosyjskiego, pisząc o najeździe Napoleona na Rosję w Wojnie i pokoju. Tołstoj pod egidą „boskości” i „świętości” cara Aleksandra I prowadzi Rosję do zwycięstwa nad Napoleonem, którego Julia Kuragina w swym liście określa jako „korsykańskie straszydło”. ${ }^{20}$ Nieustępliwa amplifikacja utwierdza współczesnego Tołstojowi czytelnika (Nataszę Rostowa jako bohaterkę powieści przede wszystkim) w przekonaniu, że zwycięstwo Mojżesza nad Amalikiem i Dawida nad Goliatem, kojarzone z Moskwą w sensie politycznym i religijnym, wydadzą i tym razem owoce zwycięstwa armii cara Aleksandra I: „Владыко Господи! [...] укрепи силою твоею благочестивейшего, самодержавнейшего великого государя нашего императора Александра Павловича. [...] воздаждъ ему по благости его, ею же хранит ны, твой возлюбленный Израиль [...]. [...] утверди всемогушною твоею десничею иарство его и подажь ему победу на врага, яко же Моисею на Амалика, Гедеону на Мадиама и Давиду на Голиафа." 21

Wojna 1812 roku była, jak wiadomo, spowodowana zerwaniem przez Rosję traktatu podpisanego przez Napoleona i Aleksandra I w Tylży (9 lipiec 1807 r.) po bitwie pod Frydlandem (14 czerwiec 1807 r.), gdzie Napoleon pokonał zdecydowanie wojska rosyjskie i niedobitki wojsk pruskich (Baczkowski 2005, s. 357). W 1810 roku Rosja wystapiła z systemu blokady kontynentalnej, umożliwiajacc tym samym Anglii handel. Sztab rosyjski opracował plan wojny ofensywnej z Napoleonem. Na początku 1811 roku przedstawiono carowi plan ataku na Gdańsk i Warszawę. Napoleon w związku z tym podją zamiar zmuszenia Rosji do respektowania zobowiązań podjętych w Tylży. Wiązało się to z zawiązaniem Konfederacji Generalnej Królestwa Polskiego, która głosiła wskrzeszenie Polski i przyłączenie do niej prowincji bezprawnie zawłaszczonych przez Rosję po II rozbiorze, co wiązało się z rozerwaniem wewnętrznego rynku krajowego, ${ }^{22}$ przejęciem zachodniej

18 Poslanija Ivana Groznogo. Red. V. P. Adrianova Peretc. Moskva - Leningrad: Izdatel'stvo Akademii Nauk SSSR, 1951, s. 403.

19 GORCZYCA, Wojciech: Iwan IV Groźny. Op. cit., s. 35.

20 GORCZYCA, Wojciech: Utopizmy Lwa Totstoja (1852-1869). Bielsko-Biała: Wydawnictwo Naukowe Akademii Techniczno-Humanistycznej, 2015, s. 61.

21 TOLSTOJ, Lev Nikolajevič: Vojna i mir. T. III-IV. Moskva: Eksmo, 2006, s. 78-79.

22 ŚLUSAREK, Krzysztof: Rzeczpospolita w XVIII wieku. In: Wielka historia świata. Świat w XVIII wieku. T. VIII. Red. P. Franaszek. Warszawa: Świat Książki, 2005, s. 338-339. 
części Ukrainy na północ i południe od Kijowa, masowym wywłaszczaniem właścicieli ziemskich. ${ }^{23}$

Motyw ofiarnictwa mający swe źródło w wojującym profetyzmie Moskwy, wiąże się immanentnie z samopoświęceniem. Wojna z Napoleonem, podobnie jak wyprawa Gró́nego na Kazań, otrzymuje błogosławieństwo ze strony cerkwi prawosławnej, jakkolwiek sprawcą wojny nie jest „korsykańskie straszydło” tylko car Aleksander I, stojący na czele państwa zmilitaryzowanego i postępujący, jeśli chodzi o zarządzanie krajem, bardziej jako okupant niż monarchowie absolutni w sensie zachodnim. ${ }^{24}$ Przeczy to zupełnie spojrzeniu św. Tomasza z Akwinu na problem wojny, który dopuszczał wojnę jako dochodzenie sprawiedliwości np. w sytuacji, kiedy szkoda wyrządzona przez przeciwnika jest długotrwała, poważna i niezaprzeczalna. ${ }^{25} \mathrm{~W}$ tym sensie św. Tomasz z Akwinu był bliski Staremu Testamentowi. Napoleon rozpoczynając wojnę z Rosją nie niszczył kraju, a później nie spalił jego stolicy. Jego wojska dość długo maszerowały przez tereny, które przed rozbiorami należały do Polski (stąd dobre zaopatrzenie wojska przez miejscową szlachtę). Kraj niszczył i to w barbarzyński sposób Aleksander I, stosując scytyjską taktykę spalonej ziemi.

Napoleon jako „Amalik” nie tylko chciał zmusić Aleksandra I do respektowania ustaleń traktatu w Tylży, chciał także ujawnić „ciśnienie wolności” dyskredytujące wojskowy profil władzy w Rosji, będący spadkiem po najeździe tatarsko-mongolskim. Aleksander I jako „Mojżesz” podtrzymał decyzję swojej babki, Katarzyny II, o wymazaniu Polski z mapy Europy, w tym wymazaniu artykułu 5 Konstytucji III Maja: „Wszelka władza społeczności ludzkiej początek bierze z woli narodu".

W ten sposób Tołstoj przyznając Aleksandrowi I status „Mojżesza”, odwrócił znaczenie wojny Starotestamentowej jako wojny sprawiedliwej - w obronie swego narodu. „Mojżesz” nie walczył z „Amalikiem” o wolność, ponieważ już wcześniej uznał, że „ktucie, cięcie, palenie $i$ grabienie”26 jest lepsze aniżeli ustrój stanowy, znajdujący swój wyraz w pluralizmie prawa, szczególnie zaś w zmierzaniu do kodyfikacji prawa obowiązującego ogół ludzkości. ${ }^{27}$

W ten sposób właśnie uznał Tołstoj Polaków za „Amalekitów”, którzy w II wojnie z Rosją u boku Napoleona zmierzali ku odzyskaniu bezprawnie im zabranej wolności. Dlatego wojnę „obronną”, jak określa się w źródłach rosyjskich tę wojnę, uznać należy za degradację i wulgaryzację istoty wojny Starotestamentowej.

W sensie etyczno-politycznym Armia konna Izaaka Babla reprezentuje podobny typ rozumienia wojny sprawiedliwej, tj. „obronnej”, z jakim spotykamy się u Iwana Groźnego w Listach oraz Wojnie i pokoju Lwa Tołstoja. Już na wstępie Babel uznaje Polskę za „przybysza-gwałciciela”: „Вот Польша, вот надменная скорбъ Речи Посполитой! Насильственный пришелеи. Речь Посполитая, горе гебе". ${ }^{28}$

23 THOMPSON, Ewa: Trubadurzy imperium. Przeł. A. Sierszulska. Kraków: Universitas, 2000, s. 155.

24 PIPES, Richard: Rosja carów. Przeł. Wł. Jeżewski. Warszawa: Wydawnictwo Magnum, 2010, s. 141.

25 Wojna w Biblii. Dostęp: https://www.gotquestions.org/Polski/wojna-wBiblii.html.

26 GORCZYCA, Wojciech: Utopizmy Lwa Totstoja (1852-1869). Op. cit., s. 108.

27 BARDACH, Juliusz - LEŚNODORSKI, Bogusław - PIETRZAK, Michał: Historia państwa i prawa polskiego. Warszawa: Lexis Nexis, 2009, s. 335-339.

28 BABEL, Isaak: Konarmija. Dostępne: lib.ru/PROZA/BABEL/Konarmija.modernlib.net/.../Konarmija/ Real. 
W ten sposób prowokuje do ekskursu w historię Polski i Rusi. Sięgnijmy do faktów historycznych, które swój początek znajdują w wyzwoleniu Rusi Kijowskiej spod jarzma mongolskiego przez Litwę oraz włączeniu do Polski Rusi Halickiej przez króla Kazimierza III Wielkiego. Skądinąd wiadomo, że Ruś Zaleska (i Andrzej Bogolubski, który spacyfikował Kijów w 1169 roku) zdążała do zbudowania centrum religijno-politycznego w Moskwie. Jednak zarówno Moskwa jak i Kijów zostały podbite przez wojska Batu chana (1237 r.), którego czapki po prawie siedmiuset latach przejęli kawalerzyści Budionnego i Gaja chana jako symbol panmongolizmu i rewolucji jednocześnie. ${ }^{29} \mathrm{~W}$ wyniku zrzucenia jarzma tatarsko-mongolskiego, Ruś Kijowska (też Ruś Siewiero-Czernihowska) weszła w obręb Wielkiego Księstwa Litewskiego, którego granice leżały 100 km od Moskwy.

Za czasów panowania króla Kazimierza III Wielkiego przyłączona została do Polski w 1340 roku Ruś Halicka (z Haliczem, Lwowem, Chełmem i Bełzem), część Rusi Włodzimierskiej oraz Podole aż do Dniestru. Kazimierz Wielki otworzył kraj dla Żydów prześladowanych w zachodniej Europie. W 1334 roku wydał przywilej biorący Żydów pod opiekę królewską i zezwalający im na uprawianie działalności gospodarczej, szczególnie handlu. Z kolei małżeństwo Władysława Jagiełły z Jadwigą zapoczątkowało chrystianizację Litwy w porządku rzymskim (katolickim) a nie prawosławnym, wiążąc ją z kulturą zachodnią. ${ }^{30}$

Traktat rozbiorowy z 5 sierpnia 1772 roku przyznał Rosji Inflanty oraz województwo połockie, witebskie, mścisławskie i mińskie oraz tereny na wschód od Dźwiny i Dniepru. W wyniku II rozbioru Polski (23 styczeń 1793 r.) do Rosji zostały przyłączone: część woj. wileńskiego i mińskiego, wschodnia część woj. nowogródzkiego, brzesko-litewskiego i woj. kijowskie. Po III rozbiorze Polski Rosji przypadły ziemie po Bug i Niemen. ${ }^{31}$

Babel w Armii konnej uznaje tylko „prawomocne” decyzje carycy Katarzyny II dotyczace rozbiorów Polski, co pozwala mu traktować w wojnie 1919-1921 roku Polaków jako Amelekitów. Podobnie jak Amalekici stali się typem narodu wrogim Żydom, symbolem wrogości wobec Izraela, tak i Polacy jako agresorzy są warci, jak pisze Babel, tylko „ognia upajającej zemsty". Zresztą w opinii historiografów rosyjskich funkcjonuje do dzisiaj przekonanie, że Rosja nie dokonała rozbiorów Polski, tylko odzyskała to, co jej się należało. Jest to zgodne z ustaleniem Iwana Groźnego, że tereny Prusa, który był protoplasta Ruryka i bratem cesarza Oktawiana Augusta leżały między Wisłą i Niemnem. ${ }^{32}$ Twierdzi się także, iż Finlandia i Polska przyłączyły się do Rosji na „dogodnych warunkach”. ${ }^{3}$

W Armii konnej Polacy są wrogą siłą, która morduje nie tylko żołnierzy Budionnego, lecz także Żydów. Otrzymują zarówno od narratora jak i bohaterów (np. Żyda Gedalego) miano psów i świń (Горъкое презрение к псам и свинъям человечества...; Поляк злая собака). Stary Testament psa i świnię uznaje za zwierzę nieczyste, tj. takie, którego nie należy spożywać. Nie oznacza to jednak, że zwierzęta te symbolizują zło. Koń, jakkolwiek

29 GORCZYCA, Wojciech: Stanistaw Haykowski (1902-1943). Utan i malarz batalista. Bielsko-Biała: Wydawnictwo Naukowe Akademii Techniczno-Humanistycznej, 2018, s. 30-31.

30 TOPOLSKI, Jerzy: Historia Polski. Poznań: Wydawnictwo Poznańskie, 2003, s. 82-88.

31 ŚLUSAREK, Krzysztof: Rzeczpospolita w XVIII wieku. Op. cit., s. 335-341.

32 GORCZYCA, Wojciech: Iwan IV Groźny. Op. cit., s. 25.

33 TOMASZEK, M.: „Pravdy” Nikity Sokolova. In: Tekst literacki i tekst kultury w glottodydaktyce. Red. W. Gorczyca. Bielsko-Biała: Wydawnictwo Akademii Techniczno-Humanistycznej, 2010. 
w Starym Testamencie jest zwierzęciem nieczystym, to symbolizuje m.in. bezpieczeństwo narodowe, moc i opatrzność Boża. ${ }^{34} \mathrm{~W}$ kulturze Rosji kategoria 'pies' zyskała w dużej mierze znaczenie pejoratywne. Swoistym szczytem upodlenia psa jako zwierzęcia jest List Iwana Groźnego do Andrzeja Kurbskiego, w którym jako 'psa' określa właśnie Kurbskiego, nadto Aleksieja Adaszewa i Siemiona Rostowskiego, ${ }^{35}$ przy czym 'pies' jest kojarzony z kałem, jadem i diabłem. Aleksander Błok w poemacie Dwunastu, nazywając psa parszywym, tworzy kategorię burżuja-psa i starego świata-psa. ${ }^{36}$

Na kartach Armii konnej narrator przemieszcza się po terenach byłego zaboru rosyjskiego (Nowogród Wołyński, Żytomierz, Brody, Beresteczko, Chocim, Zamość, Czaśniki). Tubylcami są dla niego przede wszystkim Żydzi i miejscowa szlachta, winna wszystkich ich nieszczęść. Każdorazowo obecność narratora w miejscowościach, miasteczkach bez życia, które zamieszkują Żydzi, z jednej strony ewokuje dalekie wspomnienia, nostalgię, łączy się ze współczuciem, z drugiej, wskazuje winowajców takiej sytuacji - właśnie polską szlachtę. Wołyński Żyd, jego „ponura wielkość”, implikuje rozmyślanie o żydowskich dziewczętach, które były gwałcone przez polskich żołnierzy. Okrucieństwo Polaków wobec Żydów sięga zenitu w scenie, mającej miejsce w Nowogrodzie Wołyńskim, w scenie ze starym Żydem, który ma rozerwane gardło i twarz przerąbaną na pół, a krew o zabarwieniu granatowym leży na jego brodzie jak kawałek ołowiu.

Żydów mordują także Kozacy Budionnego. O ile jednak zamordowanego przez Polaków Żyda narrator wiąże z tragicznymi przeżyciami jego córki, Żydówki, będącej w ciąży, co podwaja okrucieństwo „przybyszów-gwałcicieli”, to kozacki mord jest sprawiedliwym wymiarem kary za szpiegostwo na rzecz Polaków: „Несколько казаков расгреливали за шпионаж старого еврея. Старик взвизгивл и вырывался. Кудря [...] взял его голову и спрятллее у себя под мышкой. Еврей за тих и расставил ноги. Кудря правой рукой выташил кинжал и осторожо зарезал старика”. Zwracają uwage słowa - „ осторожно зарезал”, które kojarzą się z „profesjonalna dokładnością”.

Rodzaj dyskursu, jaki wprowadza Babel w Armii konnej, tworzy możliwość ideowego utożsamienia się Żyda (Żydów) z rewolucją. Przykładem takiego utożsamienia i wrogości wobec Polaków jest stary Żyd Gedali, którego spotyka narrator w Żytomierzu. Gedali sprzedaje w sklepiku różne rzeczy, narrator siedzi z nim na beczkach po piwie pośód guzików, motylków, suchych kwiatów i dyskutuje o rewolucji, o której Gedali sądzi: „Революиия это хорочее дело хороших людей. А поляк стрелял [...], потому ито он контреволюиия".

Nieszczęścia, jakie zafundowała, według Babla, polska szlachta Żydom, z historycznego i prawnego zarazem punktu widzenia, nie są dziełem tej szlachty. Babel w ogóle nie bierze pod uwagę tych uwarunkowań. Czas historyczny, tak jak dla Marksa, dla niego nie istnieje. Liczy się przede wszystkim teraz, tj. rewolucja. Postępuje zgodnie z dyrektywami

34 POVSHEDNAYA, Oxana: Symbolika zwierzat w judaizmie biblijnym na przyktadzie Ksiegi Madrości Syracha. Bielańskie Studia Teologiczne, 2016, 2, s. 78-88. Dostęp: www.vol.jw.org/af/vol/d/r12/Lp-p/1200000591.

35 Poslanija Ivana Groznogo. Op. cit., s. 195, 290, 307.

36 GORCZYCA, Wojciech: Wschodni utopizm Wtodzimierza Sotowiowa i symbolistów rosyjskich. In: Problemy utopii i antyutopii w literaturach słowiańskich i historii Słowian. Red. W. Gorczyca i I. Pospíšil. Bielsko-Biała: Wydawnictwo Naukowe Akademii Techniczno-Humanistycznej, 2014, s. 178-179. 
Czeka, jest jednym z żołnierzy Dzierżyńskiego, pracuje, przed wyjazdem na wojnę z Polakami, w Komisariacie Oświaty wespół z Anatolem Łunaczarskim. ${ }^{37}$

Nieszczęścia Żydów, o których pisze Babel, wiążą się z faktem, iż Rosja po 1772 r. ograniczyła ich swobody osobiste, m.in. w zakresie nabywania ziemi i osadnictwa. Ograniczenie praw Żydów na terenie Rosji (Polski pod zaborem rosyjskim) kontrastowało z radykalnymi zmianami, jakim ulegała sytuacja Żydów w XVIII i XIX w. na zachodzie Europy i w Ameryce. Pełnię praw obywatelskich otrzymali najpierw we Francji (1791), później Belgii (1830), Włoszech (1870), Niemczech (1871) i Szwajcarii (1874). ${ }^{38}$

Według raportu komisji, powołanej przez prezydenta USA Woodrowa Wilsona po zakończeniu I wojny światowej do zbadania problemów Żydów w Polsce (ściślej na ziemiach byłego zaboru rosyjskiego - uzup. W. G.), główną przyczyną ekscesów antyżydowskich był rozpowszechniony w byłym zaborze rosyjskim antysemityzm ludności cywilnej i żołnierzy - głównych sprawców ekscesów. Raport podkreślił, że władze polskie - wojskowe i cywilne - nie były inicjatorem zajść, przeciwnie, starały się je poskromić. ${ }^{39}$ W czasie wojny 1919-1921 Żydzi byli często wciągani w konflikt polsko-rosyjski i oskarżano ich o sympatie probolszewickie. Konflikt ów nie był jednak wywołany przez stronę polską. Polska w latach 1919-1920 broniła się przed najazdem bolszewickim, przez rewolucją światową. ${ }^{40}$

Aby osiągnąć sukces i wejść na szczyty rewolucji światowej należało wykazać się, tak jak „Herakles w kołysce” ${ }^{41}$ bezwględnym męstwem, umiejętnością zabijania, czy raczej mordowania bez najmniejszych zahamowań. Reprezentatywnym przykładem mordowania z zimną krwią jest scena zatytułowana „Мой первый гусь”. Wyprzedza ona scenę ze starym Żydem zamordowanym za szpiegostwo. Metodycznie, z zimną krwią dokonany na gęsi mord (przygięcie szyi gęsi do ziemi i nadepnięcie na nią butem, cieknąca krew, złożone skrzydła) jest akceptowany przez obserwujących Kozaków. Mordujący (narrator) zostaje ugoszczony przez Kozaków gorącym kapuśniakiem, za co odwdzięcza się im przeczytaniem fragmentu przemówienia Lenina. Udane polowanie na gęś wyakcentowało tak potrzebną bolszewikowi energię i gotowość, a motyw kolektywizmu (kibicujący mordowi Kozacy) został połączony z ideą braterstwa w imię obrony wolności oraz imieniem nowego „Boga” - Lenina.

Tora odróżnia „zabijanie” od morderstwa. Bóg nie jest przeciw zabijaniu, ale raczej przeciw mordowaniu. Mordowanie oznacza nieetyczne, bezprawne pozbawienie życia. Tora w wielu okolicznościach zezwala na zabijanie (np. w obronie własnej), lub nakazuje

37 ŚLIWIŃSKA, Kamila Magdalena: Postawa wobec rewolucji i rzeczywistości sowieckiej pisarza Izaaka Babla (1894-1939). In: Tejże: Literackie środowisko Odessy wobec rewolucji i rzeczywistości sowieckiej, s. 22-71 Dostęp: https://repozytorium-amu.edu.pl/bitstream,10593/9321/1/Sliwinska_PHD.pdf.

38 GORCZYCA, Wojciech: Chtodny Dom i Mongolia Wewnętrzna w pisarskiej wizji Wasyla Aksionowa $i$ Wiktora Pielewina. In: Współczesny świat słowiański, II. Red. K. Feruga i A. Ostrowska-Knapik. Praha: Verbum, 2016, s. 13-14. Dostępne: http://www.ks.ath.bielsko/plwspolczesny-swiat-slowianski.

39 Żydzi w Galicji. Dostęp: www.irekw.internetdsl.pl/zydzi_w_galicji.

40 GORCZYCA, Wojciech: Stanistaw Haykowski (1902-1943). Op. cit., s. 29-31.

41 GORCZYCA, Wojciech: Literatura rosyjska. Aspekty kulturowe. Bielsko-Biała: Wydawnictwo Naukowe Akademii Techniczno-Humanistycznej, 2016, s. 160. 
stosowanie kary śmierci - np. za morderstwo (Problem z przykazaniem „Nie zabijaj”...). W Armii konnej Babel rozpatruje relację zabijanie - mordowanie w oparciu o cytowany „dokument” (co ma uwiarygodnić problem), tj. „Biografię Mateusza Rodionycza Pawliczenki”, któremu rewolucja stworzyła możliwości awansu z pastucha na generała. W sramach „biografii” generała, niegdysiejszego pastucha z Kraju Stawropolskiego, narrator cytuje list Lenina napisany do niego. Podniesione do rangi „wysokiego prawa w imię przyszłego świetlanego życia" ustalenie Lenina stwarza generałowi Pawliczence możliwość wydawania nieograniczonych wyroków i realizowania nieograniczonych sposobów zabijania - raczej mordowania różnych ludzi „zgodnie z jego zapatrywaniami”. Zgodnie z tym „ustaleniem” pastuch-generał Pawliczenko „znęca się godzinę szablą” nad szlachcicem Nikitińskim, który odbił mu Nastię.

Motyw pastucha ma, jak wiadomo, istotne miejsce w mitologii antycznej, w tym chaldejskiej, oraz Starym Testamencie. Pastuch przede wszystkim broni stada - jest mężny, co odnotowane zostało na płaskorzeźbie chaldejskiej. Pastuch nie tylko broni, także opiekuje się stadem. Owa „opiekuńczość” wyeksponowana została w micie o Heraklesie, kiedy to został oddany pod opieką jednego z pasterzy Amfitriona, Teutarosa, Scyty, który nauczył go łucznictwa. Według jednej z wersji mitu o Edypie, pasterz koryncki znalazł syna Lajosa w górach i nadał mu imię Edyp (ponieważ stopy miał zniekształcone od ran) i oddał królowi Koryntu, Polibosowi, który nie mógł mieć potomstwa. Wiązać to można z kategorią opiekuńczości i zapobiegliwości.. Mitologia grecka przypisała także pastuchowi cechy wielce pejoratywne, m.in. z wojną związane. Trzody Geriona, jak wiadomo, strzegł pastuch Eurytion, syn Aresa, który poległ od pałki Heraklesa. ${ }^{42}$

Wprowadzając na scenę zdarzeń wojny polsko-bolszewickiej generała Pawliczenkę, Babel ogrywa motyw pastucha jako „broniącego stada”, tj. potrafiącego zabić zagrażającego stadu. W tym sensie bliski jest mu profil pastucha Eurytiona. Jednocześnie szybki awans ( $\mathrm{z}$ „pastucha-mędrca” na generała) wiąże ideologicznie z możliwościami, jakie stwarza ludziom prostego pochodzenia państwo leninowskie.

„Rewolucyjny” motyw pastucha ukuł dla literatury rosyjskiej Walery Briusow w wierszu pt. Pastuch chaldejski, napisanym w 1898 roku. Pastuch jawi się Briusowowi jako mag potrafiący odczytać tajemnice świata. On to bowiem znalazł nazwy dla znaków Zodiaku, zakreślił drogę planet. Kategoria pastucha jako mędrca koresponduje u Briusowa z kategorią Scyty - intelektualisty (też wojownika i sportsmena), obecną w wierszu pt. Scytowie (1899). Wiersz Pasterz chaldejski jest kolejnym przejawem budowania mitu związanego ze zjawiskiem panmongolizmu, wykreowanym przez Włodzimierza Sołowiowa i będącym zapowiedzią rewolucji kulturowej. Jak widać, Babel był wiernym uczniem Briusowa, który po 1917 roku wraz z Wiaczesławem Iwanowem współpracował z Anatolem Łunaczarskim. ${ }^{43}$ Pastuch-generał Pawliczenko to nie jedyny pastuch w Armii konnej.

Saszka Chrystus (Saszka Christos) zawsze marzył o zostaniu pastuchem, ponieważ, jak sądził, wszyscy święci wyszli z pastuchów. W czasie polskiej kampanii pełnił u Budionnego

42 GRAVES, Robert: Mity greckie. Przeł. H. Krzeczkowski. Warszawa: Państwowy Instytut Wydawniczy, 1974, s. $416,443,452$.

43 GORCZYCA, Wojciech: Prawdy o micie, symbolu i historii. Briusow, Iwanow, Gumilow. Bielsko-Biała: Wydawnictwo Naukowe Akademii Techniczno-Humanistycznej, 2008, s. 28-31, 60-61. 
funkcję oboźnego z tego względu, że został inwalidą w wyniku walk z Białymi. Przed wojną domowa był pastuchem w chutorze. Jako potulny (dlatego nazwano go Saszką Chrystusem) mężnie stawał w obronie swej matki przed ojczymem, który był syfilitykiem (был порченный). Ojczym chciał go za to zabić. Modus struktury tej postaci nawiązuje niewątpliwie do postaci Abla - pasterza, a poprzez to do Jezusa Chrystusa - Dobrego Pasterza (Majewski, Prehistoria biblijna). Abel symbolizuje konflikt rolnik - pasterz. Praca pasterza, niewymagająca tak dużego wysiłku jak praca rolnika została przez Boga Starotestamentowego wysoko oceniona. Bóg stawia wyżej pustynnych nomadów (pasterzy), jakimi byli Izraelici, od osiadłych mieszkańców miast i wsi. ${ }^{44} \mathrm{Na}$ pustyni pasterze byli bliżsi prorokom.

Postać Saszki Chrystusa otwiera interesująco horyzont zdarzeń lat 1918-1920, kiedy to oficjalnie Boga unicestwiono, a pomimo to w strukturach mentalnych Kozaków można było dostrzec sublimację rytualno-magiczną, która ocierała się o prawdy z Nowym Testamentem i postacią Jezusa Chrystusa związane. Bablowi, jakkolwiek „potulność” Saszki Chrystusa - pastucha wykorzystuje w dużej mierze instrumentalnie, nie można odmówić kilku trafnych charakterystyk związanych m.in. z kulturą życia i bycia ludzi z tzw. nizin społecznych.

Babel w młodości pobierał prywatne lekcje języka hebrajskiego i Talmudu. ${ }^{45}$ Znał zatem stanowisko Boga Starotestamentowego w kwestii zabijania - mordowania. Jako związany z Czeką od początku rewolucji, do Armii konnej, która została utworzona w listopadzie 1919 roku, zgłosił sie pod fałszywym nazwiskiem Kiriłła Lutowa. Udział w wojnie polsko-bolszewickiej jako reportera dał mu możliwość literackiego uzewnętrznienia programowych założeń rewolucji Lenina, w tym nauczania, jak powinien ciąć „obnażony miecz proletariatu”. Wódz rewolucji „nic niesłusznego” nie dostrzegał w mordach i samosądach organizowanych przez motłoch. Twierdził: „Trzeba pobudzać energię i masowość terroru przeciwko kontrrewolucjonistom". ${ }^{46}$ Babel w Armii konnej jest wierny takiemu stanowisku Lenina. „Nic niesłusznego” nie widzi nie tylko w metodycznym mordzie Żydów i Polaków, lecz także w naigrawaniu się z kultury polskiej, deprecjonowaniu chrześcijaństwa, w tym religii katolickiej szczególnie.

Armia konna to w dużym stopniu „manifest komunistyczny”, pochwała partii jako „,̇elaznego szeregu żołnierzy”, oddających krew - żołnierzy, którzy po śmierci mogą spotkać się w „królestwie niebieskim”. Lutow ma w tym miejscu wszakże wątpliwości, ponieważ, jak sądzi, w niebie u „starca” nie ma królestwa, raczej dom publiczny, więc może się jednak tam nie zobaczą. Jest więc zgodny z twierdzeniem Lenina, że religia to „tumanienie mas”, „obskurantyzm” i „kołtuństwo”. ${ }^{47}$ Polacy, „przybysze-gwałciciele”, powinni, parafrazując fragment z Ksiegi Wyjścia, przyłapani na włamaniu, otrzymać cios i umrzeć. Nie pociąga to za sobą winy za przelanie ich krwi (Ksiega Wyjścia, 22).

44 MAJEWSKI, Marcin: Prehistoria biblijna. Dostępne: http://bractwoslowa.pl/wp-content/uploads/2018/ 02/5.-PREHISTORIA-BIBLIJNA-Rdz-1-11-Marcin-Majewski-A-10-II-2018.pdf.

45 ŚLIWIŃSKA, Kamila Magdalena: Postawa wobec rewolucji i rzeczywistości sowieckiej pisarza Izaaka Babla (1894-1939). Op. cit., s. 68-70.

46 SMAGA, Józef: Narodziny i upadek imperium. ZSRR 1917-1990. Kraków: Wydawnictwo Znak, 1992, s. 31.

47 Tamże, s. 60. 
Z inicjatywy Lenina Sownarkom 23 stycznia (5.02.) 1918 roku wydał dekret o oddzieleniu Cerkwi od państwa i szkoły. W związku z tym na masową skalę prowadzono walkę z obyczajowością prawosławną ${ }^{48}$ Taką walkę z religią katolicką prowadzi Babel w Armii konnej - występuje przeciw jej „bałwochwalczej tyranii”. Bohaterem walczącym z Polakami i profanującym ich religie jest Afońka Bida, Kozak, którego konia zabili Polacy. Afońka nad trupem konia, „Stefana”, wybija pokłony swojemu bogu i przysięga, że pomści śmierć zwierzęcia (беспощадно же буду рубать несказанную шляхху). Afońka nie tylko palił i grabił okoliczne wioski, rozstrzeliwał polskich starostów. Rozrąbał w jednym z kościołów Beresteczka grobowiec z relikwiami św. Walentego i pijany próbował grać na organach. Walczył w imię swego boga i swego nieżyjącego już konia nie tylko ze szlachtą, także, w jego mniemaniu, $\mathrm{z}$,bałwochwalstwem”.

$\mathrm{Z}$ podobnym rodzajem sublimacji rytualno-magicznej, która sprawia, ze bohater literacki prosi swego boga, aby pomógł mu zabić (zamordować) wroga, spotykamy się w Kozakach Lwa Tołstoja, kiedy to Kozak Łukaszka przed oddaniem strzału do Abreka, wypowiada: „Отиу и сыну и святому духу”. ${ }^{49}$ Tołstoj, jak wiadomo, odrzucał dogmat o podwójnej naturze Jezusa Chrystusa (człowiek i Bóg w jednej osobie). Był bliski Bogu Starotestamentowemu. Zarówno u Tołstoja jak i Babla mamy do czynienia z systemem praktyk symbolicznych zakorzenionych $\mathrm{w}$ ideologii państwa totalitarnego, które, jeśli chodzi o religię, uwzględniało pozycję Boga Starotestamentowego - w Rosji do 1917 roku „Boga” cara; w ZSSR, „Boga” Lenina. Łukaszka i Afońka nie różnią się od siebie niczym, jeśli chodzi o rytualno-magiczne rozumienie zabijania-mordowania. Niuanse różnicy, jeśli chodzi o Afońkę, są takie, że w większym stopniu kieruje nim zemsta i krew jak na kawalerzystę Budionnego przystało, co powoduje, że nie tylko morduje. Niszczy i bezcześci wiarę chrześcijańską - Nowy Testament, przekonany, że Bóg będzie mu sprzyjać.

„Zerojedynkowo”, tj. według regulaminu ,żołnierza rewolucji”, postrzega swoją „misję” naczelny wódz Armii Konnej, Siemion Budionny - niegdyś carski wachmistrz: „Жмem нас гад [...]. [...] Победим или подхнем”. W tym sensie nawiązuje do fragmentu z Ksiegi Samuela (15:18): „Obtożysz klatwa tych występnych Amalekitów, będziesz z nimi walczyt, aż ich zniszczysz". Budionny jako dowódca armii (командарм) w wyobrażeniu Babla ma wszelkie dane, aby pokonać „Amalekitów”, tj. świetnie prezentuje się w czerwonych spodniach ze srebrnym lampasem, dysponuje olśniewającym uśmiechem, a na dodatek, co, z estetycznego punktu widzenia, wchodzi w ostry konflikt z tymi walorami, potrafi powiedzieć: „Жиет нас гад”.

Srebrny lampas w spotkaniu z polskimi ułanami pod Komarowem i Czaśnikami został całkowicie „postrzępiony”. Do wielkiej klęski Armii Konnej Babel się nie przyznaje. Wprowadza dane, podobnie jak Lew Tołstoj, jeśli chodzi o bitwę pod Ostrownem i Borodino, niezgodne z istniejącym stanem rzeczy. Przegraną zamienia na zwycięstwo. ${ }^{50}$ Dobrze znane w historii wojny polsko-bolszewickiej zdarzenie związane $\mathrm{z}$ odwołaniem Stalina, który nie zgodził się na odstąpienie od oblężenia Lwowa i podążanie wojsk

48 Tamże, s. 61.

49 GORCZYCA, Wojciech: Utopizmy Lwa Totstoja (1852-1869). Op. cit., s. 99.

50 Tamże, s. 66-67, 78-79. 
sowieckich w kierunku Warszawy w celu wspomożenia Tuchaczewskiego, Babel pomija. Zatrzymaniem się Armii Konnej pod Zamościem w celu zdobycia miasta i jego ograbienia też się zbytnio nie interesuje. Pisze jedynie: „,...] w myśl rozkazu powinniśmy nocować w Zamościu”. W podsumowaniu stwierdza, że zwycięstwo wojsk polskich, które nazywa „sawinkowcami” (od nazwiska esera i terrorysty, przeciwnika bolszewików, Borysa Sawinkowa, który szukał pomocy u Józefa Piłsudskiego i jej nie znalazł), co jest kalumnią, było krótkotrwałe i spowodowane tym, iż nie zwrócono uwagi na nadlatującą eskadrę samolotów. Pomimo to cała dywizja, pięć tysięcy ludzi, przemieściła się po zboczach wzgórz. Nieprzyjaciel pozostał na tych wzgórzach.

Dodać w tej sytuacji należy dwie informacje. Pierwsza to taka, że bitwa pod Komarowem rozegrana 31 sierpnia 1920 roku, była, obok bitwy warszawskiej, najważniejszym wydarzeniem, które zdecydowało o zwycięstwie wojsk polskich nad sowieckimi w wojnie 1919-1921 roku. Zarazem była to największa od 1813 roku bitwa kawalerii. I Dywizja Jazdy Polskiej walczyła z dwoma dywizjami jazdy Budionnego, które zostały rozbite, tracąc 2/3 składu osobowego z 6000 tysięcy walczących. Straty polskie to około 300 poległych i rannych z 1500 składu osobowego. ${ }^{51}$

Druga informacja ma związek z tradycją Starego i Nowego Testamentu w Rosji. Przetłumaczenia Starego Testamentu, konkretnie Księgi Izajasza i Księgi Hioba, na język rosyjski dokonał archimandryta Makary (Głuchariow) do 1839 roku. Tłumaczenie całości Biblii Makarego synod zaaprobował dopiero w 1859 roku. Za aprobatą synodu w 1878 roku opublikowano cała Biblię, znana jako „przekład synodalny”. ${ }^{52}$ Do tego czasu znajomość Biblii była przywilejem duchowieństwa i wybranych osób, np. pochodzących z arystokracji. Najwięksi dla Rosjan pisarze, jako trubadurzy imperium, Aleksander Puszkin (np. wiersz Prorok) i Lew Tołstoj (np. Kozacy, Wojna i pokój) bazowali na Starym Testamencie. Car był dla wszystkim Bogiem - jego władza pochodziła od Boga. Podkreślał to jeszcze w jednym ze swoich wystąpień car Aleksander III.

Babel w Armii konnej jest spadkobiercą tych tradycji, z tą różnicą, że w o wiele większym stopniu wulgaryzuje Stary Testament w interpretowaniu relacji zabijanie-mordowanie, pozostając wiernym, jako bliski czekistom, nauce Lenina. U autora Armii konnej tak jak u Tołstoja w Kozakach, pobrzmiewają groźne echa tradycji idące od Żywota Aleksandra Newskiego, który, jak Mojżesz modli się do Boga o zwycięstwo na Amalekitami. Transfer tego rodzaju „modlitwy” uobecnia się w zachowaniu Kozaków. Jeden z bohaterów Babla, Andriuszka, prosi wprost: „[...] побелел и засмеялсл, - господа Иисуса хоругву мать! И стал наводить на аэроплан пулемет”. Andriuszka w sposób „unowowcześniony”, tj. według tradycji idącej od Iwana Groźnego, który jako chorąży Chrystusa na ikonie Błogosławione zastępy Pana Niebieskiego wraca na czele wojsk ruskich spod Kazania-Sodomy, „bezwiednie” zabija Jezusa Chrystusa.

51 GORCZYCA, Wojciech: Stanistaw Haykowski (1902-1943). Op. cit., s. 32-34.

52 Biblia Makarego. Dostęp: https://pl.wikipedia.org/wiki/Biblia_Makarego. 


\section{Bibliografia}

\section{Teksty źródłowe}

BABEL, Isaak: Konarmija. Dostępne: lib.ru/PROZA/BABEL/Konarmija.modernlib.net/.../Konarmija/Real.

GRAVES, Robert: Mity greckie. Przeł. H. Krzeczkowski. Warszawa: Państwowy Instytut Wydawniczy, 1974.

Księga Rodzaju, Księga Wyjścia, List do Rzymian, Księga Jozuego, Ksiega Samuela (1, 2). In: Pismo Święte w przekładzie Nowego Świata. Nowy Jork: Towarzystwo Biblijne i Traktatowe, 1997.

Poslanija Ivana Groznogo. Red. V. P. Adrianova Peretc. Moskva - Leningrad: Izdatel'stvo Akademii Nauk SSSR, 1951.

Stowo o życiu i śmierci wielkiego księcia Dymitra Iwanowicza, cara ruskiego. Dostępne: http://www. pushinskijdom.ru/Default.aspx?tabid=4985.

TOLSTOJ, Lev Nikolajevič: Vojna i mir. T. III-IV. Moskva: Eksmo, 2006.

Żywot Aleksandra Newskiego. In: JAKUBOWSKI, Wiktor - ŁUŻNY, Ryszard. Literatura staroruska: wiek XI-XVII. Antologia. Warszawa: PWN, 1971.

\section{Artykuły, monografie}

BACZKOWSKI, Michał: Kontynent europejski w latach 1789-1849. In: Wielka historia świata. Świat w latach 1800-1850. Tom IX. Red. A. Chwalba. Warszawa: Świat Książki, 2006.

BARDACH, Juliusz - LEŚNODORSKI, Bogusław - PIETRZAK, Michał: Historia państwa i prawa polskiego. Warszawa: Lexis Nexis, 2009.

Biblia Makarego. Dostęp: https://pl.wikipedia.org/wiki/Biblia_Makarego.

BILLINGTON, James: Ideologia Moskiewska. In: Chrześcijaństwo Rusi Kijowskiej. Białorusi, Ukrainy i Rosji (X-XVII wiek). Red. J. Kłoczowski. Kraków: PAU, 1997.

BUŁAWA, Katarzyna: Tropologiczny sens Żywota Aleksandra Newskiego oraz Stowa o życiu i śmierci wielkiego księcia Dymitra Iwanowicza, cara ruskiego. Studia Slavica XIV, 2010, s. 73-90.

BURZYŃSKA, Anna: Kulturowy zwrot teorii. In: Kulturowa teoria literatury. Gtówne pojęcia i problemy. Red. M. P. Markowski i R. Nycz. Kraków: Universitas, 2006.

DRAWICZ, Andrzej: Lata dwudzieste. Proza. In: Historia literatury rosyjskiej XX wieku. Red. tenże. Wyd 2. Warszawa: PWN, 2002.

DUDA, Katarzyna: Literatura rosyjska XX wieku. In: Rosjoznawstwo. Red. L. Suchanek. Kraków: Wydawnictwo Uniwersytetu Jagiellońskiego, 2004.

FONNESBERG-SCHMIDT, Iben: Papieże i krucjaty battyckie 1147-1254. Przeł. B. Solecki. Warszawa: Bellona, 2009.

GIEYSZTOR-MIŁOBĘDZKA, Elżbieta: Symbol we wnętrzu kościelnym. In: Symbol i poznanie. Red. T. Kostyrko. Warszawa: PWN, 1987.

GORCZYCA, Wojciech: Prawdy o micie, symbolu i historii. Briusow, Iwanow, Gumilow. Bielsko-Biała: Wydawnictwo Naukowe Akademii Techniczno-Humanistycznej, 2008.

GORCZYCA, Wojciech: Iwan IV Groźny. Portret kulturowy wtadcy. Bielsko-Biała: Wydawnictwo Naukowe Akademii Techniczno-Humanistycznej, 2012. 
GORCZYCA, Wojciech: Wschodni utopizm Wtodzimierza Sotowiowa i symbolistów rosyjskich. In: Problemy utopii i antyutopii w literaturach słowiańskich i historii Słowian. Red. W. Gorczyca i I. Pospíśil. Bielsko-Biała: Wydawnictwo Naukowe Akademii Techniczno-Humanistycznej, 2014.

GORCZYCA, Wojciech: Utopizmy Lwa Totstoja (1852-1869). Bielsko-Biała: Wydawnictwo Naukowe Akademii Techniczno-Humanistycznej, 2015.

GORCZYCA, Wojciech: Chtodny Dom i Mongolia Wewnętrzna w pisarskiej wizji Wasyla Aksionowa $i$ Wiktora Pielewina. In: Współczesny świat słowiański, II. Red. K. Feruga i A. Ostrowska-Knapik. Praha: Verbum, 2016. Dostępne: http://www.ks.ath.bielsko/plwspolczesny-swiat-slowianski.

GORCZYCA, Wojciech: Literatura rosyjska. Aspekty kulturowe. Bielsko-Biała: Wydawnictwo Naukowe Akademii Techniczno-Humanistycznej, 2016.

GORCZYCA, Wojciech: Stanistaw Haykowski (1902-1943). Utan i malarz batalista. Bielsko-Biała: Wydawnictwo Naukowe Akademii Techniczno-Humanistycznej, 2018.

GREŃ, Sabina: Mongotowie i Rusini. Stowo o życiu i śmierci wielkiego księcia Dymitra Iwanowicza, cara ruskiego. In: Współczesny świat słowiański, II. Red. K. Feruga i A. Ostrowska-Knapik. Praha: Verbum, 2016. Dostępne: http://www.ks.ath.bielsko/plwspolczesny-swiat-slowianski.

JAKUBOWSKI, Wiktor: Piśmiennictwo zjednoczonego państwa moskiewskiego (1500-1630). In: Historia literatury rosyjskiej. Red. M. Jakóbiec. Warszawa: PWN, 1976.

MAJEWSKI, Marcin: Prehistoria biblijna. Dostępne: http://bractwoslowa.pl/wp-content/uploads/2018/02/5.-PREHISTORIA-BIBLIJNA-Rdz-1-11-Marcin-Majewski-A-10-II-2018.pdf.

MAKAROVA, I. A.: Socialističeskij realizm. In: Russkaja literatura XX veka. Red. S. I. Tišina. Sankt-Peterburg 2002.

MARKOWSKI, Michał Paweł: Badania kulturowe. In: Teorie literackie XX wieku. Red. A. Burzyńska i tenże. Kraków: Universitas, 2007.

PAWŁOW, Andriej - PIERRIE, Maureen: Iwan IV Groźny. Car i tyran. Przeł. Sł. Kędzierski. Warszawa: Bellona, 2008.

PIPES, Richard: Rosja carów. Przeł. Wł. Jeżewski. Warszawa: Wydawnictwo Magnum, 2010.

POVSHEDNAYA, Oxana: Symbolika zwierząt w judaizmie biblijnym na przyktadzie Księgi Madrości Syracha.

Bielańskie Studia Teologiczne, 2016, 2. Dostęp: www.vol.jw.org/af/vol/d/r12/Lp-p/1200000591.

SMAGA, Józef: Narodziny i upadek imperium. ZSRR 1917-1990. Kraków: Wydawnictwo Znak, 1992.

ŚLIWIŃSKA, Kamila Magdalena: Postawa wobec rewolucji i rzeczywistości sowieckiej pisarza Izaaka Babla (1894-1939). In: Tejże: Literackie środowisko Odessy wobec rewolucji i rzeczywistości sowieckiej. Dostęp: https://repozytorium-amu.edu.pl/bitstream,10593/9321/1/Sliwinska_PHD.pdf.

ŚLUSAREK, Krzysztof: Rzeczpospolita w XVIII wieku. In: Wielka historia świata. Świat w XVIII wieku. T. VIII. Red. P. Franaszek. Warszawa: Świat Książki, 2005.

SUCHICH, Igor Nikolajevič: Epos. „Konarmija” I. Babelja. In: Russkaja literatura XX veka. Red. S. I. Tišina. Sankt-Peterburg: 2002.

SZYLNIK, Lew: Czarne dziury historii Rosji. Przeł. M. Leczycka. Warszawa: Bellona, 2011. THOMPSON, Ewa: Trubadurzy imperium. Przeł. A. Sierszulska. Kraków: Universitas, 2000.

TOMASZEK, M.: „Pravdy” Nikity Sokolova. In: Tekst literacki i tekst kultury w glottodydaktyce. Red.

W. Gorczyca. Bielsko-Biała: Wydawnictwo Akademii Techniczno-Humanistycznej, 2010.

TOPOLSKI, Jerzy: Historia Polski. Poznań: Wydawnictwo Poznańskie, 2003. 
Wojna w Biblii. Dostęp: https://www.gotquestions.org/Polski/wojna-wBiblii.html.

Żydzi w Galicji. Dostęp: www.irekw.internetdsl.pl/zydzi_w_galicji.

Wojciech Gorczyca, profesor emeritus

ul. Bratnia 35B, 43-354 Czaniec, Polsko

wgorczyca@ath.bielsko.pl

wojtekgorczyca42@gmail.com 
